\title{
Pathogenicity and virulence of entomopathogenic nematodes against Dichelops melacanthus Dallas (Hemiptera: Pentatomidae)
}

\author{
Patogenicidade e virulência de nematoides entomopatogênicos \\ contra Dichelops melacanthus Dallas (Hemiptera: Pentatomidae)
}

\author{
Bruna Aparecida Guide ${ }^{*}$; Viviane Sandra Alves ${ }^{2}$; Thiago Augusto Paes Fernandes ${ }^{3}$; \\ Matheus Corseti Marcomini ${ }^{4}$; Ana Maria Meneghin5; Pedro Manuel Oliveira \\ Janeiro Neves ${ }^{6}$
}

\begin{abstract}
Resumo
Infestações e danos de Dichelops melacanthus (Dallas) (Hemiptera: Pentatomidae), na cultura do milho e trigo no Brasil tem aumentado nos últimos anos, principalmente devido à sua capacidade de sobreviver ao período de entressafra. O controle deste inseto é realizado principalmente com inseticidas químicos, porém o desenvolvimento de métodos alternativos, como o controle biológico, pode contribuir para um manejo mais sustentável. Assim, o objetivo deste estudo foi avaliar o potencial de nematoides entomopatogênicos (NEPs) no controle de $D$. melacanthus. O teste de seleção foi realizado com 15 isolados dos gêneros Steinernema e Heterorhabditis quanto à patogenicidade e virulência sobre adultos de $D$. melacanthus. Foram realizados, também, teste de concentrações $(10,20,40$, 50 e 100 juvenis infectantes (JIs) $/ \mathrm{cm}^{2}$ ) e teste em casa-de-vegetação, nos quais utilizou-se apenas o isolado Steinernema feltiae (IBCB-n 47). Todos os experimentos foram conduzidos em delineamento inteiramente casualizado. Os dados do teste de seleção foram submetidos ao teste de médias de ScottKnott $(\mathrm{P} \leq 0,05)$ e os do ensaio em casa-de-vegetação ao Teste-t de Student. Os resultados do ensaio de concentrações foram submetidos à análise de regressão. Todos os isolados apresentaram patogenicidade e virulência sobre adultos de D. melacanthus. Os isolados GL (Heterorhabditis amazonensis), IBCB-n27 (Steinernema sp.) e RSC05 (H. amazonensis) foram os mais virulentos (80,0; 82,0 e 88,0\% de mortalidade respectivamente). As concentrações mais altas de $S$. feltiae $\left(50\right.$ e $\left.100 \mathrm{JIs} / \mathrm{cm}^{2}\right)$ foram responsáveis pelas maiores taxas de mortalidade dos percevejos ( 88,0 e $86,0 \%$ respectivamente). No teste realizado em casa-de-vegetação, S. feltiae causou mortalidade (38\%) superior ao controle.

Palavras-chave: Controle microbiano. Steinernema. Heterorhabditis. Percevejo barriga-verde.
\end{abstract}

\section{Abstract}

Infestations of Dichelops melacanthus (Dallas; Hemiptera: Pentatomidae) in corn and wheat in Brazil, and the subsequent damage, have increased in recent years, mainly owing to this insect's ability to

${ }^{1}$ Bióloga, Dr ${ }^{\mathrm{a}}$ em Agronomia, Universidade Estadual de Londrina, UEL, Londrina, PR, Brasil. E-mail: bruhguide@gmail.com

2 Prof ${ }^{\mathrm{a}}$ Dra $^{\mathrm{a}}$, Departamento de Biologia, Universidade Estadual do Norte do Paraná, UENP, Cornélio Procópio, PR, Brasil. E-mail: vivialves@uenp.edu.br

3 Biólogo, Discente, Curso de Mestrado, Programa de Pós-Graduação em Agronomia, UEL, Londrina, PR, Brasil. E-mail: thiagouenp@gmail.com

${ }^{4}$ Eng $^{0}$ Agr ${ }^{\text {a }}$, Discente, Curso de Mestrado, Programa de Pós-Graduação em Agronomia UEL, Londrina, PR, Brasil. E-mail: matheusmarcomini11@outlook.com

5 Eng $^{\mathrm{a}}$ Agr $^{\mathrm{a}}$, Dr ${ }^{\mathrm{a}}$., Pesquisadora, Instituto Agronômico do Paraná, IAPAR, Londrina, PR, Brasil. E-mail: meneguim@iapar.br

6 Prof. Dr., Departamento de Agronomia, UEL, Londrina, PR, Brasil. E-mail: pedroneves@uel.br

Author for correspondence 
survive the off-season. The control of this insect is mainly carried out with chemical insecticides, but the development of alternative methods, such as biological control, can contribute to a more sustainable management. Thus, the objective of this study was to evaluate the potential of entomopathogenic nematodes (EPNs) for the control of D. melacanthus. A selection test was performed with 15 isolates of genera Steinernema and Heterorhabditis regarding their pathogenicity and virulence on adults of $D$. melacanthus. Concentration (10, 20, 40, 50, and 100 infective juveniles (IJs) $\left./ \mathrm{cm}^{2}\right)$ and greenhouse tests were carried out only with the Steinernema feltiae isolate (IBCB-n 47). All experiments were conducted in a completely randomized design. The selection test data were submitted to the Scott-Knott averages test $(\mathrm{P} \leq 0.05)$, and those from the greenhouse test to the Student's $t$-test. The results of the concentration assay were subjected to regression analysis. All isolates showed pathogenicity and virulence in adults of D. melacanthus. The isolates GL (Heterorhabditis amazonensis), IBCB-n27 (Steinernema sp.), and RSC05 (H. amazonensis) were the most virulent (80.0, 82.0, and $88.0 \%$ mortality, respectively). The higher concentrations of $S$. feltiae $\left(50\right.$ and $100 \mathrm{IJs} / \mathrm{cm}^{2}$ ) were responsible for the highest mortality rates of green belly stink bug ( 88.0 and $86.0 \%$, respectively). In the greenhouse test, $S$. feltiae caused higher mortality (38\%) than the control.

Key words: Microbial control. Steinernema. Heterorhabditis. Belly-green stink bug.

\section{Introduction}

The green belly stink bug, Dichelops melacanthus (Dallas), is distributed throughout Brazil, especially in the agricultural producing regions between Northern Paraná and the Central West (BORTOLOTTO et al., 2016). It is believed that its occurrence is favored by the direct planting system, which offers shelter in the straw, and by the succession of soybean/corn and soybean/ wheat crops (CRUZ et al., 2016). The insects feed on fallen soybeans and weeds, surviving the offseason periods, and attacking the corn crop soon after the emergence of plants (SILVA et al., 2013; SMANIOTTO; PANIZZI, 2015).

Adults and nymphs feed near the neck of the seedlings, causing yellowing and leaf lesions (ROZA-GOMES et al., 2011). As the leaves develop, the damage increases and can induce tillering or cause plant death. Affected leaves cannot unfold and become twisted in appearance (GOMEZ; ÁVILA, 2004; ÁVILA; DUARTE, 2012).

In order to minimize damage and control $D$. melacanthus, traditional management techniques are used, such as the preventive application of synthetic chemical insecticides in seed treatment (MARTINS et al., 2006) or spraying in the initial phase of the crop, when the plant is more susceptible to green belly stink bug attacks and the main damage occurs
(CRUZ et al., 2016). Conversely, the development of alternative methods to the chemical treatment, such as biological control, can contribute to a more sustainable management, reducing the population of pests as well as the number of chemicals in the environment (LAUMANN et al., 2010).

Entomopathogenic nematodes (EPNs) of genera Steinernema and Heterorhabditis have many interesting attributes as biological control agents (GREWAL et al., 2001). They kill the host quickly, have specificity, compatibility with other entomopathogens and chemical products, can move in search for the host, are easily applied, are not harmful to vertebrates and plants, and can be produced in large-scale (FUGA et al., 2012). Moreover, EPNs are pathogens adapted to the soil and, therefore, are indicated for the control of insects that live or spend part of their lives in this environment (GREWAL et al., 2001; LEWIS et al., 2006).

There are no studies evaluating EPNs as an alternative to the control of $D$. melacanthus. Furthermore, after the corn harvest, $D$. melacanthus remains in the soil under straw or debris (BRUSTOLIN et al., 2011) and becomes a potential target for EPNs, enabling the use of these entomopathogens as an additional tool in the management of this pest. 
Therefore, this study aimed to evaluate the potential use of EPNs for the control of $D$. melacanthus through experiments carried out under laboratory and greenhouse conditions.

\section{Materials and Methods}

The insects used in the experiments were obtained from the breeding of green belly stink bugs in the Agronomic Institute of Paraná (IAPAR) of Londrina. These insects were collected in corn areas in the municipality of Iracema do Oeste, Paraná.

The green belly stink bugs were stored in transparent crystal polystyrene Gerbox ${ }^{\circledR}$ boxes $(11 \times 11 \times 3 \mathrm{~cm})$, with a maximum of 20 insects per box, lined with a sheet of paper towel, fed with organic bean pods (Phaseolus vulgaris L.), and kept in an air-conditioned chamber $\left(26 \pm 1{ }^{\circ} \mathrm{C}\right.$ and 14 hour photophase) for a maximum of three days until the experiments were installed.

The EPN isolates were supplied by the entomopathogen bank of the Entomology and Microbial Control Laboratory of the State University of Northern Paraná (Cornélio Procópio - PR) and the Biological Institute (Campinas - SP).

\section{Selection of Isolates}

In order to perform the experiments, $15 \mathrm{EPN}$ isolates (Table 1) were previously multiplied in vivo, following the methodology of Molina and Lópes (2001), in last instar caterpillars of the greater wax moth, Galleria mellonella (Linnaeus; Lepidoptera: Pyralidae).

Table 1. Entomopathogenic nematodes (Rhabditidae: Steinernematidae and Heterorhabditidae) used in the selection test against adults of the green belly stink bug Dichelops melacanthus under laboratory conditions.

\begin{tabular}{ccc}
\hline Species & Isolate & Origin \\
\hline Heterorhabditis amazonensis & RSC 05 & Benjamin Constant, AM, Brazil \\
Heterorhabditis indica & IBCB-n 05 & Itapetininga, SP, Brazil \\
Heterorhabditis bacteriophora & HP 88 & New Jersey, United States \\
Heterorhabditis sp. & NEPET 11 & Palmeira das Missões, RS, Brazil \\
Heterorhabditis amazonensis & GL & Lavras, MG, Brazil \\
Heterorhabditis sp. & JPM 4 & Lavras, MG, Brazil \\
Heterorhabditis sp. & IBCB-n 40 & Taboporã, SP, Brazil \\
Heterorhabditis sp. & IBCB-n 46 & Santo Antônio de Posse, SP, Brazil \\
Steinernema sp. & IBCB-n 27 & Mogi Guaçu, SP, Brazil \\
Steinernema carpocapsae & IBCB-n 02 & Florida, United States \\
Steinernema diaprepesi & AM 163 & Sinop, MT, Brazil \\
Steinernema rarum & PAM & Aceguá, RS, Brazil \\
Steinernema feltiae & IBCB-n 47 & Florida, United States \\
Steinernema puertoricense & CER-n 125 & Rio Verde, GO, Brazil \\
Steinernema glaseri & IBCB-n 01 & Botucatu, SP, Brazil \\
\hline
\end{tabular}

Glass Petri dishes ( $9 \mathrm{~cm}$ in diameter) with 10 adult insects were used as experimental units. The plates were lined with two sheets of dry filter paper and a $5 \mathrm{~cm}$ piece of organic bean pod was provided as food. The isolates were then applied to the entire filter paper at a concentration of 100 infective juveniles (IJs) $/ \mathrm{cm}^{2}$ (approximately $2 \mathrm{~mL} /$ plate), using micropipettes. A control was also set up with an application of $2 \mathrm{~mL}$ of distilled water. Five repetitions were performed. 
The plates were capped and kept in an airconditioned chamber (at $26 \pm 1{ }^{\circ} \mathrm{C}$, and photophase of 14 hours). After five days, the number of dead insects was recorded and the insects were dissected in order to confirm mortality using a stereoscope microscope to observe the presence of EPNs inside them.

The data were subjected to homogeneity (Hartley) and normality (Shapiro-Wilk) tests, and the mortality means were compared by the ScottKnott test $(p \leq 0,05)$ using the Sisvar statistical software version 5.6 (FERREIRA, 2011).

\section{Adequacy of concentrations}

After the selection test, a Steinernema feltiae isolate (IBCB-n 47) was chosen to be used in the subsequent tests. This assay was performed in order to determine the maximum lethal concentration and the same methodology was used as in the isolate's selection test. Five concentrations were evaluated: $10,20,40,50$, and $100 \mathrm{IJs} / \mathrm{cm}^{2}$, besides the control.

The results were subjected to regression analysis using the Sisvar statistical software version 5.6 (FERREIRA, 2011). In order to estimate the maximum lethal concentration, a derived regression equation was used, allowing the determination of the desired value in the evaluated interval.

\section{Greenhouse test and evaluation of the persistence of Steinernema feltiae}

The experiment was conducted in a greenhouse at the Londrina State University (UEL; 2319'43.3"S, $\left.51^{\circ} 12^{\prime} 14.5^{\prime \prime} \mathrm{W}\right)$ with controlled conditions of temperature $\left(27 \pm 2{ }^{\circ} \mathrm{C}\right)$ and humidity $(70 \pm 10 \%)$.

Two treatments (application of $S$. feltiae isolate IBCB-n 47 and a control without nematodes) were performed with ten repetitions. Each experimental unit consisted of a pot $(17 \mathrm{~cm}$ in diameter and a capacity of $4 \mathrm{~L}$ ) filled with soil (red latosol), in which four corn seeds (hybrid BALU 188) were sown. Fourteen days after emergence, when the plants were about $15 \mathrm{~cm}$ high, corresponding to the V1 and V3 stages (RITCHIE; HANWAY, 1989), thinning was performed and two plants were left per pot.

The nematode S. feltiae (IBCB-n 47) was applied using a five-liter knapsack sprayer regulated for deposition of $100 \mathrm{IJ} / \mathrm{cm}^{2}$ and with the jet directed and close to the neck of the plant. For this application, $550 \mathrm{~mL}$ of solution (nematode + water) were prepared, containing approximately 1400 IJs/ $\mathrm{mL}$. In each vessel, $17 \mathrm{~mL}$ of solution was applied, corresponding to $24000 \mathrm{IJ} /$ pot. Only water was used in the control.

After the application, five adult green belly stink bugs were placed in the pots. A cage (voile fabric bags, suspended by a $20 \mathrm{~cm}$ high and $17 \mathrm{~cm}$ in diameter wire frame) was attached to each pot to prevent insects from escaping.

Five days after spraying, mortality was assessed and the death of green belly stink bugs due to the action of EPNs was confirmed. The insects were then dissected using a stereomicroscope. The data were subjected to homogeneity (Hartley) and normality (Shapiro-Wilk) tests, and the averages were compared using the Student's $t$-test $(\mathrm{p} \leq 0.05)$.

After the end of the assay at the greenhouse, the persistence of nematodes in the pots was evaluated in samples of $100 \mathrm{~g}$ of soil. The soil was packed in $500 \mathrm{~mL}$ plastic pots, and five G. mellonella caterpillars were added to isolate the IJs using the "live-bait" technique (BEDDING; AKHURST, 1975). The pots were capped and stored in an airconditioned chamber (at $23 \pm 1{ }^{\circ} \mathrm{C}$ and without a photoperiod) for seven days. After this period, the assessment was made and the dead caterpillars were placed in a White trap (WHITE, 1927) for the emergence of IJs. 


\section{Results and Discussion}

Selection of Isolates

All isolates showed pathogenicity in the adults of $D$. melacanthus and the virulence varied between
46.0 and $88.0 \%$. Of the 15 evaluated isolates, eleven caused the highest mortality rates, clearly differing from the others (Table 2).

Table 2. Percentage of adult mortality (average \pm SE) of Dichelops melacanthus caused by entomopathogenic nematodes (Rhabditidae: Steinernematidae and Heterorhabditidae) under laboratory conditions. Temperature: $26 \pm 1$ ${ }^{\circ} \mathrm{C}$, photophase: $14 \mathrm{~h}$ (light):10 h (dark).

\begin{tabular}{ccc}
\hline Species (Treatments) & Isolate & Mortality (\%) \\
\hline Heterorhabditis amazonensis & RSC 05 & $88.0 \pm 7.5 \mathrm{a}$ \\
Steinernema sp. & IBCB-n 27 & $82.0 \pm 8.6 \mathrm{a}$ \\
Heterorhabditis amazonensis & GL & $80.0 \pm 5.4 \mathrm{a}$ \\
Steinernema diaprepesi & AM 163 & $78.0 \pm 3.7 \mathrm{a}$ \\
Heterorhabditis sp. & IBCB-n 46 & $76.0 \pm 8.9 \mathrm{a}$ \\
Steinernema glaseri & IBCB-n 01 & $74.0 \pm 5.0 \mathrm{a}$ \\
Steinernema feltiae & IBCB-n 47 & $72.0 \pm 9.1 \mathrm{a}$ \\
Heterorhabditis bacteriophora & HP88 & $70.0 \pm 5.4 \mathrm{a}$ \\
Steinernema puertoricense & CER-n 125 & $70.0 \pm 4.4 \mathrm{a}$ \\
Heterorhabditis sp. & IBCB-n 40 & $68.0 \pm 7.3 \mathrm{a}$ \\
Heterorhabditis sp. & NEPET 11 & $68.0 \pm 5.8 \mathrm{a}$ \\
Steinernema carpocapsae & IBCB-n 02 & $64.0 \pm 5.0 \mathrm{~b}$ \\
Steinernema rarum & PAM & $62.0 \pm 7.3 \mathrm{~b}$ \\
Heterorhabditis sp. & JPM 4 & $58.0 \pm 3.7 \mathrm{~b}$ \\
Heterorhabditis indica & IBCB-n 05 & $46.0 \pm 9.7 \mathrm{~b}$ \\
Control & - & $10.0 \pm 4.4 \mathrm{c} *$ \\
\hline CV (\%) & & 20.8 \\
\hline
\end{tabular}

*Averages followed by the same lowercase letter in the column did not differ significantly by the Scott-Knott test ( $\mathrm{p} \leq 5 \%$ ).

These results corroborate another study using nematodes against pest bugs. The pathogenicity and virulence of $H$. bacteriophora and S. feltiae on adults of the bug Cyrtomenus bergi (Froeschner; Hemiptera: Cydnidae) corroborate with results by Melo et al. (2006). However, the nematode $H$. bacteriophora showed higher virulence, causing $42.2 \%$ mortality, a result lower than that observed in this study.

Furthermore, in an isolate selection test aimed at the control of the leafhopper Mahanarva spectabilis (Distant; Hemiptera: Cercopidae) we previously observed that all isolates were pathogenic to insects and that Steinernema carpocapsae, S. feltiae, S. riobrave, and $H$. amazonensis caused mortalities higher than $80 \%$ to fourth/five instar nymphs (BATISTA et al., 2014).

The virulence of three nematodes was also evaluated on Aeneolamia varia (Distant; Hemiptera: Cercopidae). H. bacteriophora was the most virulent, causing $76 \%$ of mortality in insects (SALGUERO et al., 2012). Other studies, under laboratory and greenhouse conditions, demonstrated the virulence of isolates of genera Steinernema and Heterorhabditis in the coffee root mealybug Dysmicoccus spp. (Hemiptera: Pseudococcidae) (ANDALÓ et al., 2004; ALVES et al., 2009a; GUIDE et al., 2016). 
These differences can be explained by the specificity of different isolates for different hosts due to several factors, such as its efficiency reaching the host, penetrating and causing infection, and the ability to "trick" the insect's immune system (LEWIS et al., 2006).

We did not find previous studies evaluating isolates of EPNs over D. melacanthus and other Hemiptera of the family Pentatomidae. Thus, our study is the first to indicate the potential of using EPNs to cause mortality in these phytophages.

\section{Concentration testing}

The $S$. feltiae isolate was used for concentration testing because it was among the most virulent isolates of the selection test. Also, it has characteristics that favor its action as a biological control agent, such as high multiplication capacity (RAHOO et al., 2017), which results from its fast life cycle and enables the production of several generations in short periods of time.

Steinernema feltiae caused mortality of adults of D. melacanthus in all tested concentrations. The mortality percentage varied between 34.0 and $88.0 \%$, and the higher concentrations (50 and $100 \mathrm{IJ} / \mathrm{cm}^{2}$ ) were responsible for the highest mortality rates (88.0 and $86.0 \%$, respectively; Figure 1). According to Rahoo et al. (2017), the chance of infection of an insect can be influenced by the number of nematodes applied, as higher concentrations increase the chances of infection and, consequently, of higher rates of mortality.

Figure 1. Mortality regression curve (\%) of adults of Dichelops melacanthus as a function of concentrations of the entomopathogenic nematode Steinernema feltiae (IBCBn-47; IJs $/ \mathrm{cm}^{2}$ ). Estimated maximum mortality of $93.2 \%$ with application of $79 \mathrm{IJs} / \mathrm{cm}^{2}$.

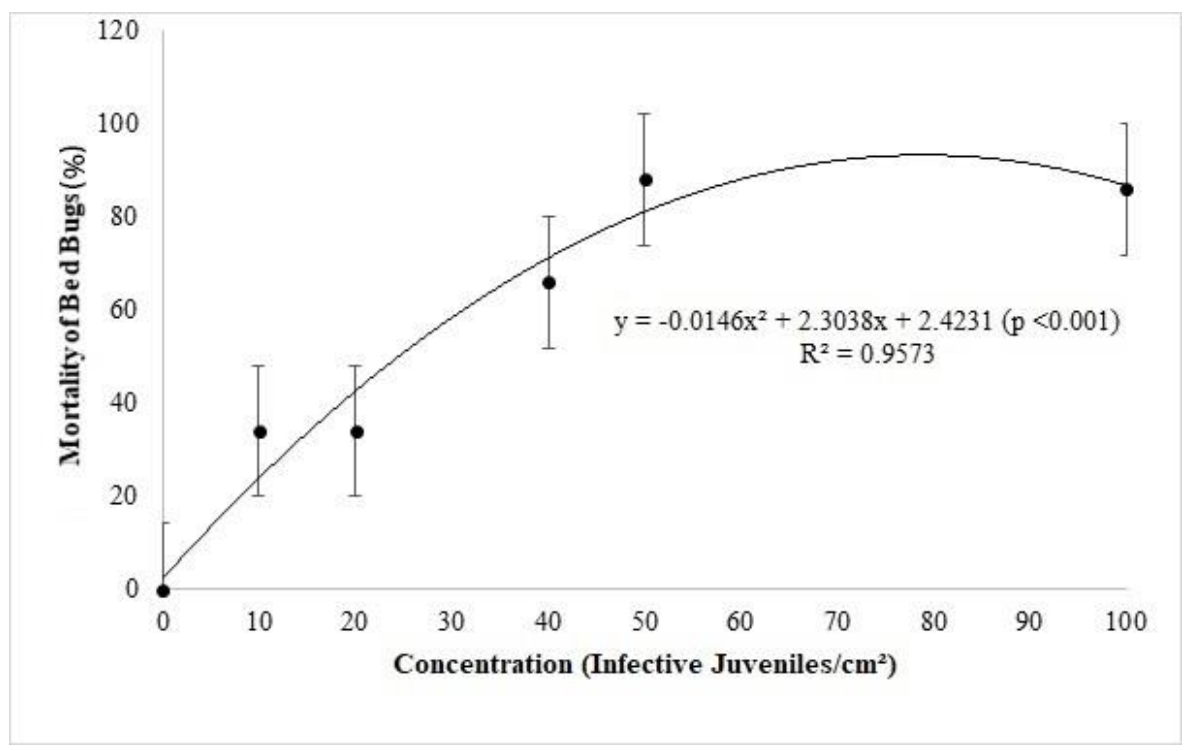

However, we observed that in concentrations of 50 and $100 \mathrm{IJs} / \mathrm{cm}^{2}$ the mortalities were similar, suggesting that concentrations higher than $100 \mathrm{IJ} /$ $\mathrm{cm}^{2}$ may cause intraspecific competition among nematodes. According to Gaugler et al. (1994) and
Selvan et al. (1993), a minimum number of IJs is required to "trick" the insect's immune system, colonize it, and cause its death. However, when this number is exceeded (when very high concentrations of EPNs are used) intraspecific competition 
compromising the survival, development, and reproduction of nematodes may occur, reducing their virulence and efficiency.

Moreover, it should be considered that the use of EPNs in pest management tends to be feasible when low concentrations are sufficient for efficient control, especially in large agricultural areas (BATISTA et al., 2014), such as those cultivated with corn, and with lower costs for production and application.
Greenhouse test and evaluation of the persistence of Steinernema feltiae

Mortality caused by $S$. feltiae isolate (IBCB-n 47) was $38 \%$ in green belly stink bugs under greenhouse conditions and was significantly higher than the control treatment (26\%; Figure 2). We observed that mortality was lower when compared to values obtained in laboratory tests.

Figure 2. Percentage of adult mortality of Dichelops melacanthus caused by Steinernema feltiae (IBCB-n 47) in greenhouse conditions.

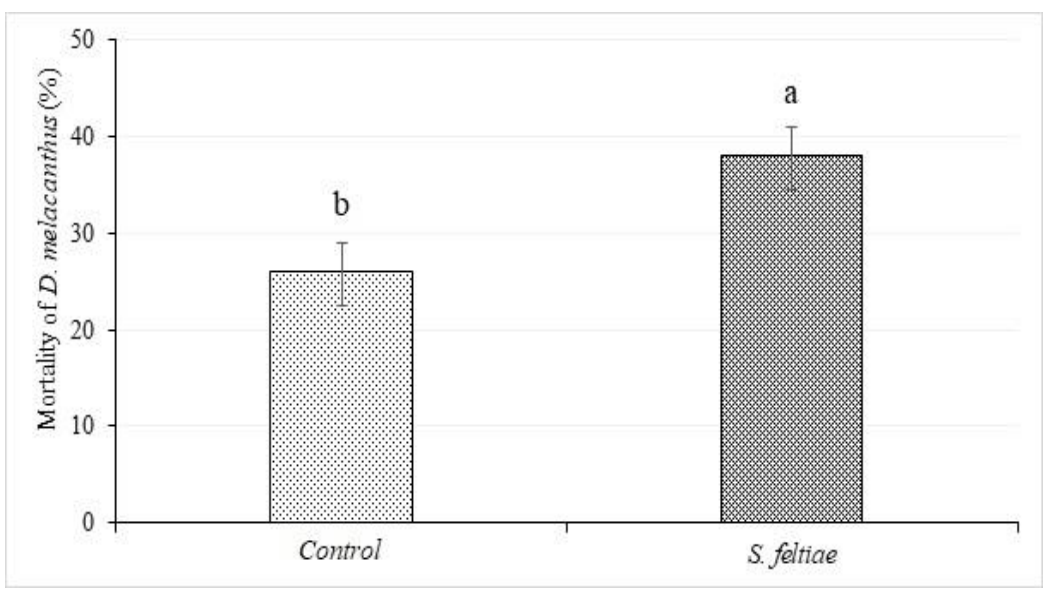

In laboratory tests, it should be taken into consideration that biotic and abiotic factors that impair field nematodes are minimized. Exposure of the insect to nematodes in a closed and controlled environment also tends to be higher. Thus, many isolates that are efficient in insect control in laboratory tests may not show the same results when taken to greenhouse or field conditions. Other factors such as the behavior of the host insect and the isolate, such as search and specificity capacity, may reduce the efficiency of field/greenhouse control (DOWDS; PETERS, 2002; ALVES et al., 2009b).

Conversely, we observed that the dissected dead green belly stink bugs had nematodes inside them, indicating that $S$. feltiae (IBCB-n 47) can multiply inside the insect. Thus, green belly stink bugs can be a source of nematode inoculum in the environment, allowing it to remain viable for longer periods of time, providing control of remaining insects after the nematodes complete their life cycle and originate new generations.

Regarding the persistence of S. feltiae (IBCB-n 47) after the application, all soil samples collected from the pots of the experiment were positive for the presence of nematodes and a mortality rate of $100 \%$ was observed in the G. mellonella caterpillars which were used for confirmation. This shows that the nematodes persisted in the soil and that the juveniles were infective after five days of application, being able to infect more individuals if they remained in the pots for a longer time. 
The persistence of entomopathogens in the environment is an important characteristic of biological control programs, and some studies have proven the high persistence of several species of EPNs under field conditions (DEL VALLE et al., 2008; ALVES et al., 2009b; GUIDE et al., 2016).

However, the data obtained in this study are the first to highlight EPNs as potential control agents for green belly stink bugs, suggesting that their use for the control of D. melacanthus may be feasible. However, further studies under greenhouse and field conditions should be conducted.

Therefore, new challenges regarding the improvement of the performance of this agent for the control of $D$. melacanthus remain. The persistence of nematodes over longer periods of time under greenhouse and field conditions should be evaluated, as well as other forms of application and different concentrations of the entomopathogen. Moreover, studies evaluating the large-scale production and formulation of the entomopathogen should be conducted in order to evaluate the feasibility of its use in the field by producers.

\section{References}

ALVES, V. S.; MOINO JUNIOR, A.; SANTA-CECILIA, L. V. C.; ANDALÓ, V.; SOUZA, G. C. Patogenicidade de nematoides entomopatogênicos a cochonilha-da-raizdo-cafeeiro Dysmicoccus texensis (Tinsley) (Hemiptera: Pseudococcidae) em laboratório. Arquivos do Instituto Biológico, São Paulo, v. 76, n. 1, p. 67-73, 2009a.

ALVES, V. S.; MOINO JUNIOR, A.; SANTACECÍlIA, L. V. C.; ROHDE, C.; SILVA, M. A. T. D. Testes em condições para o controle de Dysmicoccus texensis (Tinsley) (Hemiptera, Pseudococcidae) em cafeeiro com nematóides entomopatogênicos do gênero Heterorhabditis (Rhabditida, Heterorhabditidae). Revista Brasileira de Entomologia, Curitiba, v. 53, n. 1, p. 139143, 2009b.

ANDALÓ, V.; MOINO JUNIOR, A.; SANTA-CECILIA, L. V. C.; SOUZA, G. C. Seleção de isolados de fungos e nematoides entomopatogênicos para a cochonilhada-raiz-do-cafeeiro Dysmicoccus texensis (Tinsley). Arquivos do Instituto Biológico, São Paulo, v. 71, n. 2, p. 181-187, 2004.
ÁVILA, C. J.; DUARTE, M. M. Eficiência de inseticidas, aplicados nas sementes e em pulverização, no controle do percevejo barriga-verde Dichelops melacanthus (Dallas) (Hemiptera: Pentatomidae), na cultura do milho. BioAssay, Piracicaba, v. 7, n. 6, p. 1-6, 2012. DOI: 10.14295/BA.v7.0.72

BATISTA, E. S. D. P.; AUAD, A. M.; ANDALÓ, V.; MONTEIRO, C. M. D. O. Virulence of entomopathogenic nematodes (Rhabditida: Steinernematidae, Heterorhabditidae) to spittlebug Mahanarva spectabilis (Hemiptera: Cercopidae). Arquivos do Instituto Biológico, São Paulo, v. 81, n. 2, p. 145-149, 2014. DOI: 10.1590/1808-1657001152012

BEDDING, R. A.; AKHURST, R. J. A. Simple technique for the detection of insect parasitic rhabditid nematodes in soil. Nematologica, Leiden, v. 21, n. 1, p. 109-110, 1975. DOI: $10.1163 / 187529275 X 00419$

BORTOLOTTO, O. C.; MIKAMI, A. Y.; FREITAS, B. A. de; SILVA, G. V.; QUEIROZ, A. P. de. Aspectos biológicos de Dichelops melacanthus em três temperaturas, alimentados com grãos imaturos de milho 2B688Hx e 2B688. Ciência Rural, Santa Maria, v. 46, n. 2, p. 254-259, 2016. DOI: 10.1590/0103-8478cr20150542

BRUSTOLIN, C.; BIANCO, R.; NEVES, P. M. O. J. Inseticidas em pré e pós-emergência do milho (Zea mays L.), associados ao tratamento de sementes, sobre Dichelops melacanthus (Dallas) (Hemiptera: Pentatomidae). Revista Brasileira de Milho e Sorgo, Sete Lagoas, v. 10, n. 3, p. 215-223, 2011. DOI: 10.18512/1980-6477/rbms.v10n3p215-223

CRUZ, I.; BIANCO, R.; REDOAM, A. Potential risk of losses in maize caused by Dichelops melacanthus (Dallas) (Hemiptera: Pentatomidae) in Brazil. Revista Brasileira de Milho e Sorgo, Sete Lagoas, v. 15, n. 3, p. 386-397, 2016. DOI: 10.18512/1980-6477/rbms. v15n3p386-397

DEL VALLE, E. E.; DOLINSKI, C.; SOUZA, R. M. Dispersal of Heterorhabditis baujardi LPP7 (Nematoda: Rhabditida) applied to the soil as infected host cadavers. International Journal Pest Management, Londres, v. 54, n. 2, p. 115-122, 2008. DOI: 10.1080/09670870701660579

DOWDS, B. C. A.; PETERS, A. Virulence mechanisms. In: GAUGLER, R. Entomopathogenic nematology. Wallingford: CABI, 2002. 388 p.

FERREIRA, D. F. Sisvar: a computer statistical analysis system. Ciência e Agrotecnologia, Lavras, v. 35, n. 6, p. 1039-1042, 2011. DOI: 10.1590/S141370542011000600001

FUGA, C. A. G.; FERNANDES, R. H.; LOPES, E. A. Nematoides entomopatogênicos. Revista Trópica: 
Ciências Agrárias e Biológicas, Chapadinha, v. 6, n. 3, p. 56-75, 2012.

GAUGLER, R.; WANG, Y.; CAMPBELL, J. F. Aggressive and evasive behaviors in Popillia japonica (Coleoptera: Scarabaeidae) larvae: defences against entomopathogenic nematode attack. Journal Invertebrate Pathology, New York, v. 64, n. 3, p. 193-199, 1994. DOI: 10.1016/S00222011(94)90150-3

GOMEZ, S. A.; ÁVILA, C. J. Ameaça verde. Cultivar: Grandes Culturas, Pelotas, v. 61, n. 61, p. 28-29, 2004.

GREWAL, O. S.; NARDO, E. A. B.; AGUILLERA, M. M. Entomopathogenic nematodes: potential for exploration and use in South America. Neotropical Entomology, Londrina, v. 30, n. 2, p. 191-205, 2001. DOI: $10.1590 / \mathrm{S} 1519-566 \mathrm{X} 2001000200001$

GUIDE, B. A.; SOARES, E. A.; ITIMURA, C. R.; ALVES, V. S. Entomopathogenic nematodes in the control of cassava root mealybug Dysmicoccus sp. (Hemiptera: Pseudococcidae). Revista Colombiana Entomologia, Bogotá, v. 42, n. 1, p. 16-21, 2016.

LAUMANN, R. A.; MORAES, M. C. B.; SILVA, J. P.; VIEIRA, A. M. C.; SILVEIRA, S.; BORGES, M. I. Egg parasitoid wasps as natural enemies of the neotropical stink bug Dichelops melacanthus. Pesquisa Agropecuária Brasileira, Brasília, v. 45, n. 5, p. 442-449, 2010. DOI: 10.1590/S0100-204X2010000500002

LEWIS, E. D.; CAMPBELL, J.; GRIFFIN, C.; KAYA, H.; PETERS, A. Behavioral ecology of entomopathogenic nematodes. Biological Control, San Diego, v. 38, n. 1, p. 66-79, 2006. DOI: 10.1016/j.biocontrol.2005.11.007

MARTINS, G. L. M.; MARUYAMA, L. C. T.; TOMQUELSKI, G. V.; MARUYAM, L. C. T. Efeito de alguns inseticidas sobre Spodoptera frugiperda (Lepidoptera: Noctuidae) e Dichelops sp. (Homoptera: Pentatomidae) na fase inicial da cultura do milho. Revista Cientifica Eletrônica da Agronomia, Garça, v. 5, n. 9, p. 1-11, 2006.

MELO, E. L. M.; ORTEGA-OJEDA, C. A.; GAIGL, A.; EHLERS, R. U.; BELLOTTI, A. C. Evaluation of two commercial strains of entomonematodes as control agents of Cyrtomenus bergi Froeschner (Hemiptera: Cydnidae). Revista Colombiana de Entomologia, Bogotá, v. 32, n. 1, p. 31-38, 2006.
MOLINA, J. P. A.; LÓPEZ, N. J. C. Producción in vivo de três entomonematodos con dos sistemas de infección en dos hospedantes. Revista Colombiana de Entomologia, Bogotá, v. 27, n. 1-2, p. 73-78, 2001.

RAHOO, A. M.; MUKHTAR, T.; GOWEN, S. R.; RAHOO, R. K.; ABRO, S. I. Reproductive potential and host searching ability of entomopathogenic nematode, Steinernema feltiae. Pakistan Journal of Zoology, Punjab, v. 49, n. 1, p. 229-234, 2017. DOI: 10.17582/ journal.pjz/2017.49.1.229.234

RITCHIE, S.; HANWAY, J. J. How a corn plant develops. Ames: Iowa State University of Science and Technology, Cooperative Extension Service, 1989. 21 p. (Special Report, n. 48).

ROZA-GOMES, M. F.; SALVADORI, J. R.; PEREIRA, P. R. V. S.; PANIZZI, A. R. Injúrias de quatro espécies de percevejos pentatomídeos em plântulas de milho. Ciência Rural, Santa Maria, v. 41, n. 7, p. 1115-1119, 2011.

SALGUERO, C. A. M.; PARDEY, A. E. B.; NÚÑEZ, J. C. L.; VALDERRAMA, U. C.; SÁNCHEZ, G. D. R. S. Virulence of entomopathogenic nematodes to control Aeneolamia varia (Hemiptera: Cercopidae) in sugarcane. Revista Colombiana de Entomologia, Bogotá, v. 38, n. 2, p. 260-265, 2012.

SELVAN, S.; CAMPBELL, J. F.; GAUGLER, R. Densitydependent effects on entomopathogenic nematodes (Heterorhabditidae and Steinernematidae) within an insect host. Journal Invertebrate Pathology, New York, v. 62, n. 3, p. 278-284, 1993. DOI: 10.1006/jipa.1993.1113

SILVA, J. J.; VENTURA, M. U.; SILVA, F. A. C.; PANIZZI, A. R. Population dynamics of Dichelops melacanthus (Dallas) (Heteroptera: Pentatomidae) on host plants. Neotropical Entomology, Londrina, v. 42, n. 2, p. 141-145, 2013. DOI: 10.1007/s13744-012-0104-2

SMANIOTTO, L. F.; PANIZZI, A. R. Interactions of selected species of stink bugs (Hemiptera: Heteroptera: Pentatomidae) from leguminous crops with plants in the Neotropics. Florida Entomologist, Lutz, v. 98, n. 1, p. 7-17, 2015. DOI: 10.1653/024.098.0103

WHITE, G. F. A method for obtaining infective nematodes larvae from cultures. Science, Washington DC, v. 66, n. 1709, p. 302-303, 1927. 
